\section{Timing of Drip Irrigation Initiation Affects Irrigation Water Use Efficiency and Yield of Bell Pepper under Plastic Mulch}

\author{
Mathieu Ngouajio ${ }^{1,3}$, Guangyao Wang ${ }^{1}$, and Ronald G. Goldy ${ }^{2}$
}

ADDITIONAL INDEX wORDs. Capsicum annuum, leaf water potential, soil moisture, water stress, withholding irrigation

SumMARy. Field studies were conducted in 2003 and 2004 to determine effects of withholding irrigation on pepper (Capsicum annumm) plant height, leaf chlorophyll content, yield, and irrigation water use efficiency. Irrigation treatments were initiated at pepper transplanting (S0), after transplant establishment (S1), at first flower (S2), at first fruit (S3), or at fruit ripening (S4). The control treatment received only enough water to apply fertigation (FT). Withholding irrigation did not affect pepper plant height except FT treatment, but increased leaf chlorophyll content. Withholding irrigation until S4 saved $50 \%$ and $41 \%$ of irrigation water in 2003 and 2004, respectively, without affecting fruit yield compared with the treatment where irrigation started at transplanting. However, yield in the FT treatment was significantly reduced. Irrigation water use efficiency (pepper yield per unit area per millimeter of water applied) was maximum at $S 4\left(59.1 \mathrm{~kg} \cdot \mathrm{ha}^{-1}\right.$ per millimeter) and S3 (24.1 kg.ha ${ }^{-1}$ per millimeter) in 2003 and 2004 , respectively. Similar trends in response of pepper to the irrigation treatments were observed in 2003 and 2004 even though there were large differences in rainfall, and pepper yield between years. This suggests that withholding irrigation until first fruit may help to maintain pepper yield while reducing irrigation costs. However, it is important to have adequate soil moisture at transplanting to insure adequate transplant establishment.

$\mathrm{I}$ rrigated agriculture contributes nearly $40 \%$ to world food production on $17 \%$ of cultivated land, and accounts for $70 \%$ to $85 \%$ of fresh water usage worldwide (Food and Agriculture Organization of the United Nations, 1996; Mao et al., 2003; van Schilfgaarde, 1994). Adequate water supply is required for high yields of quality produce, but at the same time, there are concerns that excessive irrigation can result in wasted water and nutrient leaching. Reducing water use in agriculture and increasing irrigation water use efficiency (IWUE) can reduce water shortages and increase water availability for

This work was supported in part by Project GREEEN (Generating Research and Extension to meet Environmental and Economic Needs; no. GR04-008), by SWMREC (Southwest Michigan Research and Extension Center), and by the Michigan Vegetable Council.

Thanks to all the growers in southwestern Michigan who contributed to the design of this experiment by sharing their ideas and experience, and to Trevor Meachum for donating pepper transplants in 2003.

${ }^{1}$ Department of Horticulture, Michigan State University, 428 Plant and Soil Sciences, East Lansing, MI 48824

${ }^{2}$ Southwest Michigan Research and Extension Center, Michigan State University, Benton Harbor, MI 49022

${ }^{3}$ Corresponding author. E-mail: ngouajio@msu.edu. other purposes while decreasing input costs.

Insufficient water supply during the growing period may reduce crop production and quality (Debaeke and Aboudrare, 2004; Smittle et al., 1994), while excess irrigation not only wastes water and increases nutrient leaching (Moreno et al., 1996; Pang et al., 1997), but can also reduce crop yield (Ngouajio et al., 2007; Phene and Sanders, 1976; Sezen et al., 2006). Because most vegetable crops are heavily fertilized, as indicated by high residual $\mathrm{N}$ levels after harvest, overirrigation can increase the risk of groundwater contamination (Greenwood et al., 1996).
Studies have been conducted to save irrigation water and reduce nutrient leaching while preserving crop yields. Changing from surface to drip irrigation (Aujla et al., 2005; Singandhupe et al., 2003), irrigation scheduling according to crop water status, searching for critical irrigation stage (Simsek et al., 2005), and partial root drying techniques (Kirda et al., 2004; Zegbe-Dominguez et al., 2003 ) have proven to reduce water requirements in many crops. These methods are especially important when irrigation water is limited or expensive. Withholding water in the early stages of vegetative growth can increase root length and allow plants to use water and nutrients from deeper in the soil, thus increasing water and nutrient use efficiency (Ludlow and Muchow, 1990; Pace et al., 1999). About 1800 acres of bell peppers are produced annually in Michigan. In 2004, total production was $522,000 \mathrm{cwt}$ with a value of about $\$ 13.6$ million (U.S. Department of Agriculture, 2005). Bell pepper is very susceptible to water stress, as well as overirrigation (Sezen et al., 2006). Irrigation is critical for pepper production. Unfortunately, the amount and distribution of precipitation events in Michigan and the midwestern United States, are uneven during the growing season and vary greatly from year to year. Therefore, most growers use supplemental irrigation to reduce the risks associated with natural rainfall patterns. Drip irrigation is commonly used for freshmarket pepper production (Sanders, 2002). However, most growers have traditionally irrigated their crop from transplanting to last harvest, as recommended for areas with less frequent rainfall (e.g., desert areas of California). This practice has led to overirrigation at the beginning of the

\begin{tabular}{llll}
\hline $\begin{array}{l}\text { Units } \\
\text { To convert U.S. to SI, } \\
\text { multiply by }\end{array}$ & U.S unit & SI unit & $\begin{array}{l}\text { To convert SI to U.S., } \\
\text { multiply by }\end{array}$ \\
\hline 0.4047 & acre $(\mathrm{s})$ & $\mathrm{ha}$ & 2.4711 \\
45.3592 & $\mathrm{cwt}$ & $\mathrm{kg}$ & 0.0220 \\
0.3048 & $\mathrm{ft}$ & $\mathrm{m}$ & 3.2808 \\
2.54 & inch(es) & $\mathrm{cm}$ & 0.3937 \\
25.4 & inch(es) & $\mathrm{mm}$ & 0.0394 \\
10.0 & inch(es)/inch & $\mathrm{mm} \cdot \mathrm{cm}^{-1}$ & 0.1 \\
1.1209 & lb/acre & $\mathrm{kg} \cdot \mathrm{ha}^{-1}$ & 0.8922 \\
28.3495 & $\mathrm{oz}$ & $\mathrm{g}$ & 0.0353 \\
6.8948 & $\mathrm{psi}$ & $\mathrm{kPa}$ & 0.1450 \\
2.2417 & ton $/ \mathrm{acre}$ & $\mathrm{t} \cdot \mathrm{ha}^{-1}$ & 0.4461 \\
$\left({ }^{\circ} \mathrm{F}-32\right) \div 1.8$ & 'F & ${ }^{\circ} \mathrm{C}$ & $\left(1.8 \times{ }^{\circ} \mathrm{C}\right)+32$
\end{tabular}

Hortectnology · July-September 2008 18(3) 
growing season in most situations (R.G. Goldy, unpublished data). Water use in agriculture is being increasingly regulated in Michigan, thereby putting more pressure on growers to reduce water use. During the early stages of plant development, it might be possible to reduce the amount of irrigation water without significantly affecting yield. This might be more feasible under plasticulture systems where plastic mulches prevent large amounts of water loss through evaporation. Therefore, this study was undertaken to measure the effectiveness of drip irrigation initiation on IWUE and yield of bell pepper.

\section{Materials and methods}

Field studies were conducted at the Southwest Michigan Research and Extension Center at Benton Harbor, Michigan $\left(42^{\circ} 6^{\prime} 12^{\prime \prime} \mathrm{N}\right.$, $86^{\circ} 21^{\prime} 32^{\prime \prime} \mathrm{W} ; 224 \mathrm{~m}$ above sea level) in 2003 and 2004. The soil is a Spinks loamy fine sand, $\mathrm{pH} 6.5$, less than $2 \%$ organic matter, with an available waterholding capacity of about $1 \mathrm{~mm} \cdot \mathrm{cm}^{-1}$. Rainfall during the two growing seasons is presented in Fig. 1.

The experiment was a randomized complete block design with six treatments and four replications. The treatments consisted of initiating irrigation at transplanting ( $\mathrm{SO}$ ), after transplant establishment (SI), at first flower (S2), at first fruit (S3), and at fruit ripening (S4). The control treatment received $\approx \mathrm{l}$ h per week of irrigation, which was only enough water (about $15 \mathrm{~mm}$ ) for fertigation (FT). All treatments were fertigated at the same time once per week. Details of the pepper growth stage and days after transplanting for each treatment are presented in Table 1. Once irrigation was started, plots with irrigation received an average weekly input of $62 \mathrm{~mm}$ of water applied daily for 1 to $2 \mathrm{~h}$ (practice used by pepper growers in the area). Randomization of all treatments was achieved by cutting the drip tapes and reconnecting treatments in consecutive blocks with solid tapes (without emitters). A buffer zone of $5 \mathrm{ft}$ was maintained between blocks. Flow meters were connected to each irrigation line (treatment) to record the amount of water delivered at each irrigation event. Natural rainfall was recorded at the site using a weather station (model 012; Campbell Scientific,

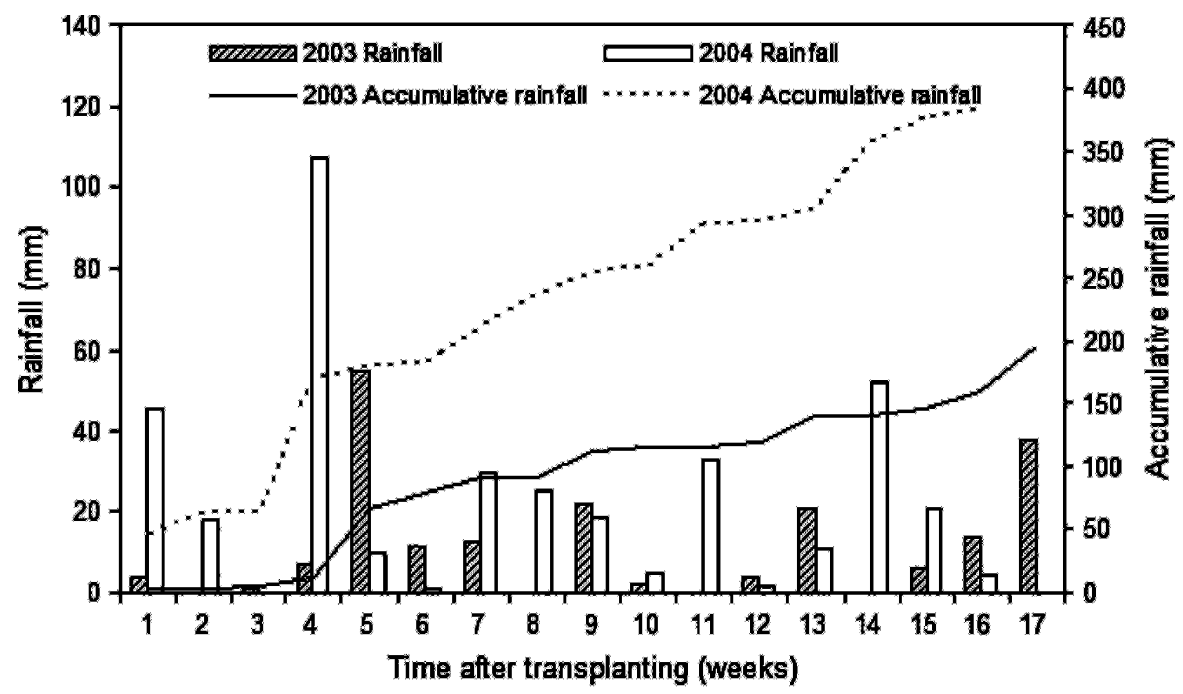

Fig. 1. Weekly rainfall during pepper growing season in Benton Harbor, Michigan, in 2003 and $2004(1 \mathrm{~mm}=0.0394$ inch $)$.

Table 1. Pepper growth stage and time after transplanting at the time of irrigation initiation in the various treatments in Benton Harbor, Michigan, in 2003 and 2004.

\begin{tabular}{|c|c|c|c|}
\hline \multirow[b]{2}{*}{ Treatment $^{\mathrm{z}}$} & \multirow{2}{*}{$\begin{array}{c}\text { Growth stage } \\
2003 \text { and } 2004\end{array}$} & \multicolumn{2}{|c|}{$\begin{array}{c}\text { Time after } \\
\text { transplanting }(d)^{y}\end{array}$} \\
\hline & & 2003 & 2004 \\
\hline So & Transplanting & 0 & 0 \\
\hline S1 & End of transplant establishment & 5 & 15 \\
\hline S2 & First flower & 21 & 28 \\
\hline S3 & First fruit & 35 & 40 \\
\hline S4 & Fruit ripening & 51 & 55 \\
\hline FT & $\mathrm{NA}^{\mathrm{x}}$ & NA & NA \\
\hline
\end{tabular}

${ }^{2}$ Irrigation treatments were initiated at pepper transplanting (SO), after transplant establishment (S1), at first flower (S2), at first fruit (S3), or at fruit ripening (S4). The FT treatment received only enough water for FT.

Because of the difference in weather conditions between 2003 and 2004, the growth stages during irrigation initiation did not correspond to the time after pepper transplanting.

${ }^{x}$ Not applicable because irrigation was only applied for FT.

Logan, UT). Individual plots consisted of one $21-\mathrm{ft}$-long bed with two rows of pepper. Spacing was 12 inches between the two rows on the same bed and 18 inches between plants in each row. 'Camelot' Bell pepper was grown using recommended practices for fresh-market plasticulture production in southwestern Michigan (Goldy et al., 2001). Sevenweek-old pepper plants were transplanted on 4 June 2003 and 20 May 2004 on raised beds covered with black plastic.

Before transplanting, the entire plot received a top dressing of 33 , 185 , and $11 \mathrm{~kg} \cdot \mathrm{ha}^{-1}$ of nitrogen $(\mathrm{N})$, potassium $(\mathrm{K})$, and boron $(\mathrm{B})$, respectively. The fertilizers were applied as $33 \mathrm{~N}-0 \mathrm{P}-0 \mathrm{~K}, 0 \mathrm{~N}-0 \mathrm{P}-49.8 \mathrm{~K}$, and Solubor DF (U.S. Borax, Valencia, CA) containing $17.5 \% \mathrm{~B}$. The field was then fumigated with methyl bromide $(67 \%$ methyl bromide and $33 \%$ chloropicrin at $300 \mathrm{lb} /$ acre) and covered with black plastic mulch. After transplanting, all treatments were irrigated to ensure good rootsoil contact, after which the application of the treatments started accordingly. Details of the fertilizers, herbicides, and fungicides used are presented in Ngouajio et al. (2007). All treatments were fertigated weekly from mid-June to the first week of September with $4 \mathrm{~N}-0 \mathrm{P}-8 \mathrm{~K}-2 \mathrm{Ca}$ to achieve $4 \mathrm{lb} /$ acre $\mathrm{N}$ per week.

Access tubes were installed in each treatment for weekly monitoring of soil moisture content at 12 , 24 , and 36 inches using a capacitance probe (200AP; Troxler Electronic Laboratories, Research Triangle Park, $\mathrm{NC)}$ connected to a portable data logger(PRISM; Precision Irrigation Scheduling Methods, Malaga, WA). 
Leaf water potential was measured using the third fully expanded leaf. Five leaves were collected in each plot before sunrise (Rudich et al., 1981), enclosed in zip-lock bags, and put in an insulated box. Leaf water potential was measured after leaf collection in all treatments using a pressure chamber (model 600; PMS Instrument Co., Albany, OR). Pepper leaf water potential was measured eight times in 2003 and nine times in 2004.

Pepper height was measured on 7 Aug. 2003 and 2 Aug. 2004. Leaf chlorophyll content was measured during flower formation by using a chlorophyll meter (model SPAD502; Minolta, Ramsey, NJ). The leaves in similar position on the plant were used and 20 measurements were taken in each plot.

Peppers were harvested six times from 7 Aug. to 18 Sept. 2003 and four times from 7 Aug. to 23 Sept. 2004. Pepper fruit were initially graded into jumbo $(\geq 240 \mathrm{~g})$, extra-large (200-239 g), large (170-199 g), medium $(<170 \mathrm{~g})$, no. 2 (usable but irregular shape), and cull. The fruit number in each grade was counted and weighed. In this article, jumbo, extra-large, and large pepper fruit were combined as large marketable fruit, whereas medium and no. 2 were combined as small marketable fruit.

IWUE $\left(\mathrm{kg} \cdot \mathrm{ha}^{-1} \cdot \mathrm{mm}^{-1}\right)$ was calculated using the following equation (Hillel and Guron, 1975):

$$
I W U E=\frac{\Upsilon_{I}-\Upsilon_{F T}}{W_{I}-W_{F T}}
$$

where $\Upsilon_{I}$ is pepper yield with irrigation and $\Upsilon_{F T}$ is pepper yield in FT treatment. $W_{I}$ is the water amount applied in irrigation treatments and $W_{F T}$ is the water amount applied in FT treatment.

All data were subjected to analysis of variance, and significant differences among means were reported using Fisher's protected least significant difference at the 5\% level of probability. All statistical analyses were conducted using the PROC GLM of SAS (version 7.1; SAS Institute, Cary, NC).

\section{Results and discussion}

RAINFALL AND IRRIGATION WATER APPLIED. There was 196 and $382 \mathrm{~mm}$ of rainfall in the 2003 and 2004 growing seasons, respectively (Fig. 1). In addition to greater rainfall in 2004, there was also a more uniform rain distribution in 2004 compared with 2003 . The average temperature during the pepper growing season (June-August) was higher in $2003\left(20.8{ }^{\circ} \mathrm{C}\right)$ than in $2004\left(19.6{ }^{\circ} \mathrm{C}\right)$. The variability between years was ideal to test how weather conditions, especially rainfall, may affect pepper response to irrigation. The total solar flux density was similar in the two growing seasons $\left(2596.6 \mathrm{MJ} \cdot \mathrm{m}^{-2}\right.$ in 2003 and 2607.4 MJ. $\mathrm{m}^{-2}$ in 2004), indicating

Table 2. Volume of water applied, pepper height, and IWUE in Benton Harbor, Michigan, in 2003 and 2004 as affected by the time of drip irrigation initiation.

\begin{tabular}{|c|c|c|c|c|c|c|}
\hline \multirow[b]{2}{*}{ Treatment $^{\mathrm{z}}$} & \multicolumn{2}{|c|}{$\begin{array}{l}\text { Water applied } \\
\qquad(\mathrm{mm})^{\mathrm{y}}\end{array}$} & \multicolumn{2}{|c|}{$\begin{array}{l}\text { Plant ht } \\
\text { (cm) }\end{array}$} & \multicolumn{2}{|c|}{$\begin{array}{c}\text { IWUE } \\
\left(\mathrm{kg} \cdot \mathrm{ha} \mathrm{a}^{-1} \text { per } \mathrm{mm}\right)\end{array}$} \\
\hline & 2003 & 2004 & 2003 & 2004 & 2003 & 2004 \\
\hline So & $1,122.1$ & 965.2 & 47.0 & $50.8 \mathrm{a}^{\mathrm{x}}$ & $23.4 \mathrm{c}$ & $14.2 \mathrm{~b}$ \\
\hline S1 & 902.2 & 876.3 & 47.6 & $47.8 \mathrm{ab}$ & $27.9 \mathrm{bc}$ & $16.9 \mathrm{ab}$ \\
\hline S2 & 772.9 & 762.0 & 45.1 & $49.5 \mathrm{a}$ & $36.1 \mathrm{bc}$ & $20.1 \mathrm{ab}$ \\
\hline S3 & 704.8 & 723.9 & 44.5 & $51.8 \mathrm{a}$ & $40.8 \mathrm{~b}$ & $24.1 \mathrm{a}$ \\
\hline S4 & 557.4 & 571.5 & 45.7 & $50.5 \mathrm{a}$ & $59.1 \mathrm{a}$ & $21.6 \mathrm{ab}$ \\
\hline FT & 100.2 & 101.6 & 43.8 & $45.0 \mathrm{~b}$ & - & - \\
\hline
\end{tabular}

${ }^{2}$ Irrigation treatments were initiated at pepper transplanting $(\mathrm{S} 0)$, after transplant establishment (S1), at first flower (S2), at first fruit (S3), or at fruit ripening (S4). The FT treatment received only enough water for FT. ${ }^{\mathrm{y}} \mathrm{l} \mathrm{mm}=0.0394$ inch; $1 \mathrm{~cm}=0.3937$ inch; $1 \mathrm{~kg} \cdot \mathrm{ha}^{-1}=0.8922 \mathrm{lb} /$ acre.

${ }^{x}$ Means are separated by Fisher's protected least significant difference test. Means within a column followed by the same letter are not significant different.
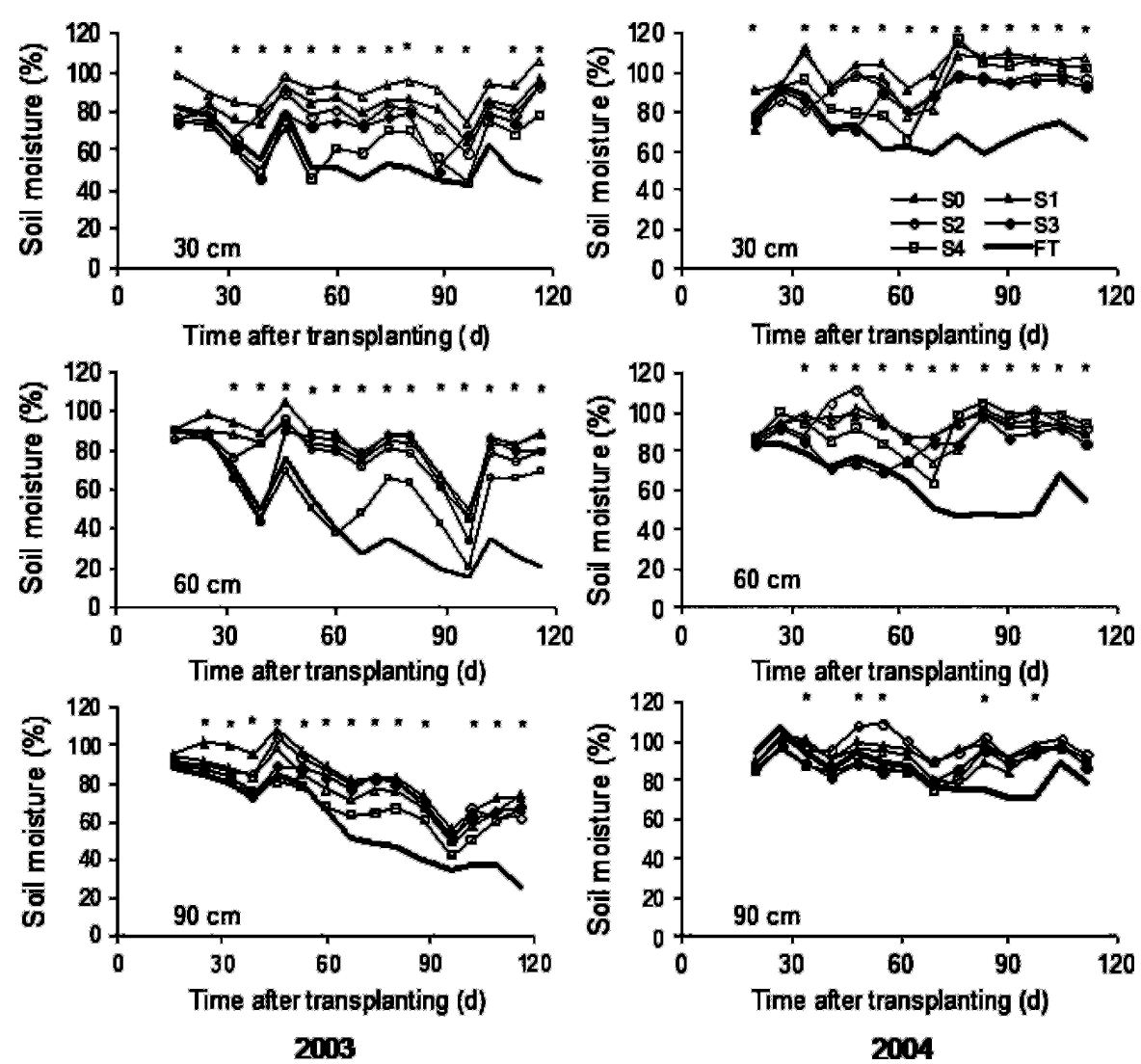

Fig. 2. Soil moisture content (percentage of available water holding capacity) at 12, 24 , and 36 inches $(30.5,61.0$, and $91.4 \mathrm{~cm})$ soil depths of the pepper field under different irrigation regimes in Benton Harbor, Michigan, in 2003 and 2004.

Irrigation treatments were initiated at pepper transplanting (S0), after transplant establishment (S1), at first flower (S2), at first fruit (S3), or at fruit ripening (S4). The FT treatment received only enough water for FT. Asterisks indicate significant differences between treatments at the specific dates. 
that any difference in pepper yield between years would likely be from differences in rainfall or heat unit accumulation rather than solar radiation.

The total amount of irrigation water applied during the growing seasons varied greatly with the treatments (Table 2). In 2003, a total of $1122,902,773,705,557$, and 100 $\mathrm{mm}$ of irrigation water was applied to S0, S1, S2, S3, S4, and FT, respectively. In 2004, the amount was 965 , $876,762,724,572$, and $102 \mathrm{~mm}$ for S0, S1, S2, S3, S4, and FT, respectively.

SOIL MOISTURE AND PEPPER LEAF WATER POTENTIAL DURING THE GROWING SEASON. Soil moisture monitoring was able to detect the effect of the treatments on soil moisture (Fig. 2 ). Withholding irrigation reduced soil moisture significantly at all three depths. The difference among treatments decreased with increasing soil depth; however, the FT treatment maintained the lowest soil moisture content throughout the growing seasons. These results suggest that under our growing conditions with raised beds on sandy soil covered with plastic mulch, there was limited lateral movement of water in the soil. Low lateral water movement (from irrigation or rainfall) in the root zone is critical for this type of study.

Although leaf water potential might be a good tool for monitoring plant water status, its ability to detect differences in the irrigation treatments was limited. In 2003, during a long period of drought, pepper leaf water potential dropped significantly in all treatments after $82 \mathrm{~d}$ after transplanting (Fig. 3). During that period, the FT plants showed significantly more stress. The difference in leaf water potential was observed at 84 , 91 , and $112 \mathrm{~d}$ after transplanting in 2004. However, the difference was minor and inconsistent compared with 2003.

Plant height and Leaf CHLOROPHYLL CONTENT. Withholding irrigation did not affect pepper plant height in 2003 (Table 2). In 2004, however, plants in the FT treatment were significantly shorter than plants in all other treatments except the Sl treatment. In 2003, we noticed that pepper leaves in the FT treatment were greener than those in other treatments. The green color of pepper leaves tended to be lighter as
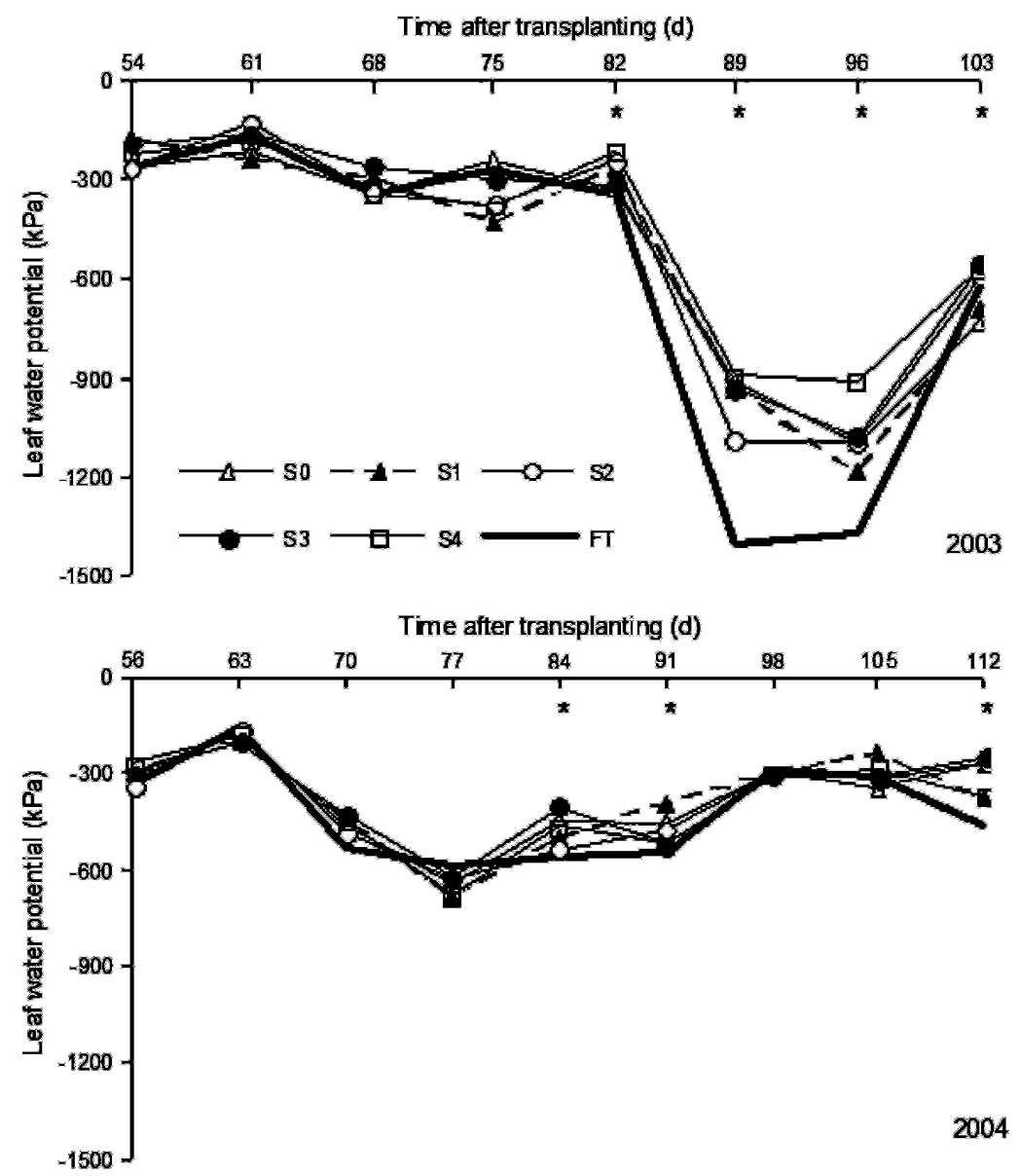

Fig. 3. Pepper leaf water potential during the growing season as affected by the irrigation regimes in Benton Harbor, Michigan, in 2003 and 2004. Irrigation treatments were initiated at pepper transplanting (S0), after transplant establishment (S1), at first flower (S2), at first fruit (S3), or at fruit ripening (S4). The FT treatment received only enough water for FT. Asterisks indicate significant differences between treatments at the specific dates $(1 \mathrm{kPa}=0.1450 \mathrm{psi})$.

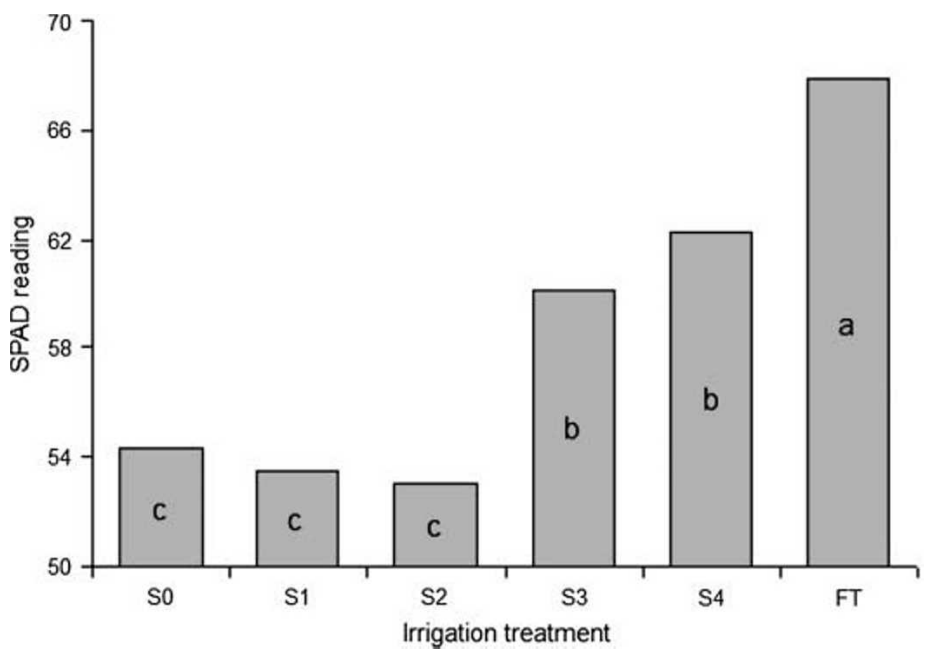

Fig. 4. Pepper leaf chlorophyll content measured at flower formation as affected by the irrigation regimes in Benton Harbor, Michigan, in 2004. Irrigation treatments were initiated at pepper transplanting (S0), after transplant establishment (S1), at first flower (S2), at first fruit (S3), or at fruit ripening (S4). The FT treatment received only enough water for FT. Means with the same letter are not significantly different using Fisher's protected least significant difference at 5\% probability. 
the amount of water applied increased. Therefore, in 2004, leaf chlorophyll content was measured to quantify these observations. Higher SPAD values indicate higher leaf chlorophyll content. Pepper leaf chlorophyll content significantly increased as irrigation was delayed ( 33 and S4) as well as with the FT treatment (Fig. 4). The SPAD values ranged from 53 for S2 to 68 for FT. The FT treatment had the highest leaf chlorophyll content, and S3 and S4 had higher leaf chlorophyll content than S0, S1, and S2.

Differences in leaf chlorophyll content were not likely caused by different plant sizes because all irrigated treatments had similar plant height. It was probably from $\mathrm{N}$ leaching by early initiation of irrigation. Unfortunately, we did not measure nutrient leaching below the root zone in this study. Simonne et al. (1998) observed a reduction in pepper leaf nutrient content with increasing irrigation water input.

Pepper fruit number and YIELD. Irrigation treatments affected pepper fruit number, yield, and fruit size (Fig. 5). In 2003, total fruit number was similar in all irrigated treatments (S0, S1, S2, S3, and S4). However, treatment S3 had more large fruit and fewer small fruit than all other irrigated treatments except S4. In 2004, FT had lower fruit number than the other treatments. The S3 treatment had higher number of large fruit than S0, S1, S2, and FT. Compared with 2003, there were generally more fruit per plant in 2004 , but more than $50 \%$ were of small size.

Lack of irrigation (FT) reduced total marketable yield compared with irrigated treatments (S0-S4) in 2003 and 2004 (Fig. 5). The yield reduction from drought stress was more pronounced in $2003(42 \%$ yield reduction) than $2004 \quad(27 \%$ yield reduction) in the FT treatment. All irrigated treatments had comparable total marketable yield in both years. There was no difference among irrigated treatments in the weight of large or small fruit in 2003. In 2004, S3 had the greatest large fruit weight and smallest small fruit yield, producing a better yield distribution than all other treatments where irrigation was initiated earlier. In previous studies, Bowen and Frey (2002)
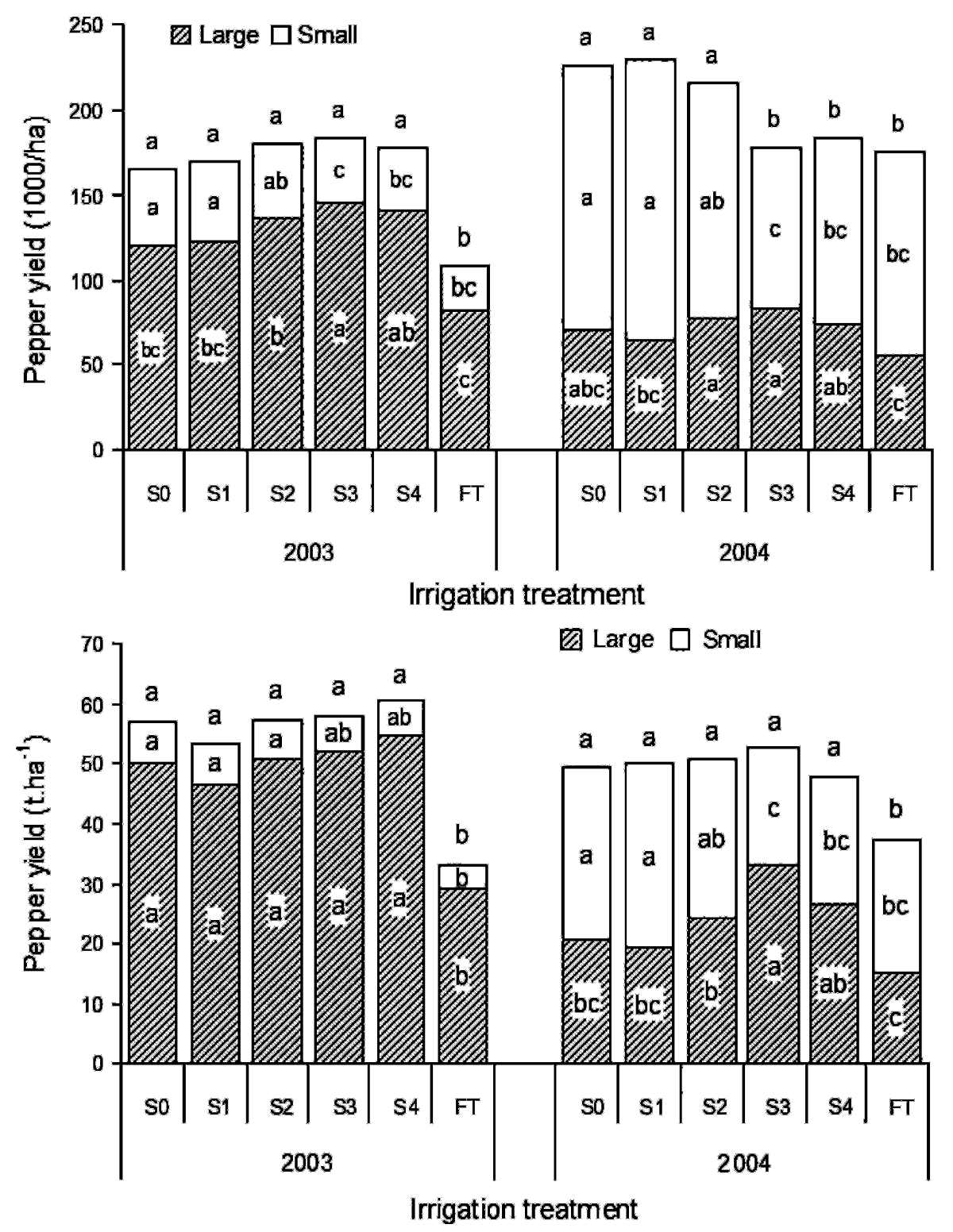

Fig. 5. Effect of irrigation regimes after transplanting on pepper fruit number and yield in Benton Harbor, Michigan. Irrigation treatments were initiated at pepper transplanting (S0), after transplant establishment (S1), at first flower (S2), at first fruit (S3), or at fruit ripening (S4). The FT treatment received only enough water for FT. Marketable fruit were graded into large $[\geq 240-199 \mathrm{~g}(8.47-7.02 \mathrm{oz})]$ and small $[<170 \mathrm{~g}(6.00 \mathrm{oz})]$ plus all usable fruit with irregular shape). For each yield category (large and small fruit), bars within 1 year with the same letter are not significantly different using Fisher's protected least significant difference at 5\% probability. Total yield is the combination of large and small fruit, and mean separation letters are indicated above the bars $(1000$ peppers $/$ ha $=404.7$ peppers $/$ acre, $1 \mathrm{t} \cdot \mathrm{ha}^{-1}=0.4461$ ton $/$ acre $)$.

also showed that excessive irrigation might not always translate into increased pepper yield.

IwUE. IWUE was maximized when irrigation was delayed until fruit ripening (S4) in 2003 and first fruit set (S3) in 2004 (Table 2).

IWUE eliminates the effects of natural rainfall to estimate the contribution of irrigation to total yield.
However, this criterion alone should not be used to make decisions on the amount of water to apply to the crop. The selling price of pepper fruit, the cost of irrigation, as well as the impact of irrigation on fruit quality, should be considered to maximize profits.

Although irrigation is critical for pepper growth in most situations (Debaeke and Aboudrare, 2004; 
Smittle et al., 1994), excessive soil moisture has been shown to slow down growth and reduce crop yield (Phene and Sanders, 1976; Sezen et al., 2006). Rainfall was more frequent and uniform in 2004 compared with 2003 (Fig. 1). That probably explains the low values of IWUE in 2004 compared with 2003. Over 2 years of study, our results were consistent even though the two growing seasons were quite different in terms of rainfall and heat unit accumulation. Our results suggest that, depending on initial soil moisture, growers could save up to $31 \%$ of irrigation water input (compared with S0) without reducing pepper yield by withholding irrigation for a few weeks after transplanting in Michigan. Similar results were previously reported for irrigation of tomato (Solanum lycopersicum) under the same growing conditions (Ngouajio et al., 2007). This consistency between years and crops suggests that, in the Great Lakes region of North America, the amount of irrigation water used for fresh-market vegetable production using plastic mulch could be significantly reduced without affecting crop yield.

The exact duration for limiting irrigation would depend on weather conditions. Withholding irrigation inputs early in the season could help reduce nutrient leaching and could enhance a deeper and more extensive root system. However, it is critical to have moist soil at planting and to avoid water deficit after first flower set. Such a practice requires monitoring soil moisture status, especially during excessively dry seasons.

\section{Literature cited}

Aujla, M.S., H.S. Thind, and G.S. Buttar. 2005. Cotton yield and water use efficiency at various levels of water and $\mathrm{N}$ through drip irrigation under two methods of planting. Agr. Water Mgt. 71:167-179.

Bowen, P. and B. Frey. 2002. Response of plasticultured bell pepper to staking, irrigation frequency, and fertigated nitrogen rate. HortScience 37:95-100.

Debaeke, P. and A. Aboudrare. 2004. Adaptation of crop management to water-limited environments. Eur. J. Agron. 21:433-446.

Food and Agriculture Organization of the United Nations. 1996. Food production: The critical role of water. 22 Nov. 2007. <http://www.fao.org/documents/ show_cdr.asp? url_file=/docrep $/ 003 /$ w2612e/w2612e7a.htm>.

Goldy, R., V. Wendzel, and D. Francis. 2001. Bell pepper yield trial, p. 19-20. In: 2001 SWMREC Vegetable Trial. Michigan State University, Southwest Michigan Research and Extension Center, Benton Harbor, MI.

Greenwood, D.J., C.R. Rahn, A. Draycott, L.V. Vaidyanathan, and C.D. Paterson. 1996. Modelling and measurement of the effects of fertilizer- $\mathrm{N}$ and crop residue incorporation on $\mathrm{N}$-dynamics in vegetable cropping. Soil Use Mgt. 12:13-24.

Hillel, D. and Y. Guron. 1975. Relation between evapotranspiration rate and maize yield. Water Res. 9:743-748.

Kirda, C., M. Cetin, Y. Dasgan, S. Topcu, H. Kaman, B. Ekici, M.R. Derici, and A.I. Ozguven. 2004. Yield response of greenhouse grown pepper to partial root drying and conventional deficit irrigation. Agr. Water Mgt. 69:191-201.

Ludlow, M.M. and R.C. Muchow. 1990. A critical evaluation of traits for improving crop yields in water-limited environments. Adv. Agron. 43:107-153.

Mao, X., M. Liu, X. Wang, C. Liu, Z. Hou, and J. Shi. 2003. Effects of deficit irrigation on yield and water use of greenhouse grown cucumber in the north China plain. Agr. Water Mgt. 61:219228.

Moreno, F., J.A. Cayuela, J.E. Fernandez, E. Fernandez-Boy, J.M. Murillo, and F. Cabrera. 1996. Water balance and nitrate leaching in an irrigated maize crop in SW Spain. Agr. Water Mgt. 32:71-83.

Ngouajio, M., G. Wang, and R. Goldy. 2007. Delaying onset of drip irrigation affects growth and yield of fresh market tomato under plasticulture. Agr. Water Mgt. 87:285-291.

Pace, P.F., H.T. Cralle, S.H.M. El-Halawany, J.T. Cothren, and S.A. Senseman. 1999. Drought-induced changes in shoot and root growth of young cotton plants. J. Cotton Sci. 3:183-187.

Pang, X.P., J. Letey, and L. Wu. 1997. Irrigation quantity and uniformity and nitrogen application effects on crop yield and nitrogen leaching. Soil Sci. Soc. Amer. J. 61:257-261.

Phene, C.J. and D.C. Sanders. 1976. High-frequency trickle irrigation and row spacing effects on yield and quality of potatoes. Agron. J. 68:602-607.

Rudich, J., E. Rendon-Poblete, M.A. Stevens, and A.I. Ambri. 1981. Use of leaf water potential to determine water stress in field-grown tomato plants. J. Amer. Soc. Hort. Sci. 106:732-736.

Sanders, D.C. (ed.). 2002. Vegetable crop guidelines for the southeastern United States 2001-2002. Vance Publishing Corp. Lenexa, KS.

Sezen, S.M., A. Yazar, and S. Eker. 2006. Effect of drip irrigation regimes on yield and quality of field grown bell pepper. Agr. Water Mgt. 81:115-31.

Simonne, E.H., D.J. Eakes, and C.E. Harris. 1998. Effects of irrigation and nitrogen rates on foliar mineral composition of bell pepper. J. Plant Nutr. 21:2545-2555.

Simsek, M., T. Tonkaz, M. Kacira, N. Comlekcioglu, and Z. Dogan. 2005. The effects of different irrigation regimes on cucumber (Cucumis sativus L.) yield and yield characteristics under open field conditions. Agr. Water Mgt. 73:173-191.

Singandhupe, R.B., G.G.S.N. Rao, N.G. Patil, and P.S. Brahmanand. 2003. Fertigation studies and irrigation scheduling in drip irrigation system in tomato crop (Lycopersicon esculentum L.). Eur. J. Agron. 19:327-340.

Smittle, D.A., W.L. Dickens, and J.R. Stansell. 1994. Irrigation regimes affect yield and water-use by bell pepper. J. Amer. Soc. Hort. Sci. 119:936-939.

U.S. Department of Agriculture. 2005. Vegetables 2004 summary. 22 Nov. 2007. <http://usda.mannlib.cornell. edu/reports/nassr/fruit/pvg-bban/ vgan0105.pdf $>$.

van Schilfgaarde, J. 1994. Irrigation: A blessing or a curse. Agr. Water Mgt. 25:203-219.

Zegbe-Dominguez, J.A., M.H. Behboudian, A. Lang, and B.E. Clothier. 2003. Deficit irrigation and partial rootzone drying maintain fruit dry mass and enhance fruit quality in 'Petopride' processing pepper (Lycopersicon esculentum, Mill.). Scientia Hort. 98:505-510. 